\title{
Rechtspraak en politiek: hoe leven die samen in het ene huis, dat democratische rechtsstaat heet?
}

\author{
Verslag van de voorjaarsvergadering 2016 van de Nederlandse Vereniging voor \\ Procesrecht
}

\author{
Mr.J.J. Dammingh en mr. L.M. vanden Berg*
}

\begin{abstract}
Algemeen
De voorjaarsvergadering van 2016 van de Nederlandse Vereniging voor Procesrecht (hierna: NVvP), die plaatsvond op 27 mei 2016, had de titel 'Rechtspraak en politiek: hoe leven die samen in het ene huis, dat democratische rechtsstaat heet?'

De voorzitter, prof. mr. C.J.M. Klaassen, heeft bij wijze van inleiding (de keuze voor) het thema van deze vergadering en de achtergronden ervan toegelicht. $\mathrm{Zij}$ memoreert dat de invloed van het bestuur (de politiek) op de zaaksbehandeling door de rechter al eerder aan de kaak is gesteld bij vergaderingen van de NVvP. Zo kwam bij de vergadering over het bewijsrecht ter sprake dat rechters zich als gevolg van de bestuurlijke wens om zaken efficiënt af te doen, min of meer gedwongen zouden voelen om bewijsverrichtingen zo veel mogelijk achterwege te laten. Bij de diverse vergaderingen over ' $\mathrm{KEI}^{1}$ is herhaaldelijk opgemerkt dat de $\mathrm{K}$ in 'KEI' weliswaar voor 'Kwaliteit' staat, maar het ministerie in het kader van 'KEI' vooral aandacht lijkt te hebben voor de digitalisering van de rechtspraak en het streven om geschillen zo efficiënt mogelijk af te doen. Een - wenselijk te achten - fundamentele herbezinning op (de kwaliteit van) de rechtspraak staat daarbij in de schaduw.
\end{abstract}

Mr. J.J. Dammingh is universitair hoofddocent burgerlijk (proces)recht aan de Radboud Universiteit Nijmegen. Mr. L.M. van den Berg is senior juridisch medewerker in de rechtbank Gelderland en tevens verbonden aan de sectie burgerlijk (proces)recht van de Radboud Universiteit Nijmegen.

1. 'KEI' ('Kwaliteit en Innovatie') is het door de Raad voor de rechtspraak en de minister van Veiligheid en Justitie geïnitieerde project gericht op het behoud en de versterking van goede, toegankelijke, eenvoudige, snelle, doelmatige en betaalbare rechtspraak. Het project moet resulteren in een nieuwe, eenvoudige, begrijpelijke, flexibele, uniforme en digitale basisprocedure, waarin de rechter de regie voert, maatwerk levert en geschillen snel en definitief beslecht. 'KEI' heeft geresulteerd in de wetsvoorstellen 34059 (strekkend tot de vereenvoudiging en digitalisering van de procedure in eerste aanleg) en 34138 (aangaande het procesrecht in hoger beroep en cassatie). De NVvP-najaarsvergadering van 2013 had als titel 'Procesinnovatie: KEIgoede ideeën?' en die van 2015 'Enkele inhoudelijke aspecten van KEI: waar gaat en waar moet het naartoe?’
Meer in het algemeen is er een toenemende bezorgdheid over de invloed die de politiek - direct en indirect - op de rechtspraak heeft. In dit verband kan onder meer de 'verbestuurlijking' van de rechtspraak worden genoemd. Hiermee wordt gedoeld op de invloed die bestuurlijke maatregelen - gericht op een zo efficiënt mogelijke geschilbeslechting - op de rechtspraak uitoefenen. Deze 'verbestuurlijking' leidt ertoe dat de juridische rationaliteit van de rechter ondergeschikt wordt gemaakt aan 'public governance'. Daarnaast kan worden gewezen op het politiek ingrijpen in de beoordelingsruimte van de rechter (denk bijvoorbeeld aan de invoering van minimumstraffen en de verschuiving van rechterlijke taken naar het Openbaar Ministerie). Ook het systeem van 'outputfinanciering' van de gerechten kan de facto resulteren in een vorm van politieke invloed op de rechtspraak. De invloed van de politiek op de rechtspraak wordt door velen ongewenst geacht.

Daar staat tegenover dat de rechter zich bij de beslechting van een geschil wel eens op het terrein van de politiek lijkt te begeven. In dit verband kan bijvoorbeeld worden gewezen op de recente Urgenda-uitspraak van de rechtbank Den Haag (over het terugbrengen van de jaarlijkse Nederlandse emissies van broeikasgassen) en de uitspraak van de rechtbank NoordNederland over de verlaging van de WOZ-waarde van woningen in het aardbevingsgebied in de provincie Groningen. ${ }^{2}$

Ook de Hoge Raad lijkt enkele keren op de stoel van de wetgever te zijn gaan zitten. Denk bijvoorbeeld aan zijn arresten over de aansprakelijkheid van de werkgever voor arbeidsongevallen en beroepsziekten. De Hoge Raad heeft daarin een verzekeringsplicht voor werkgevers geformuleerd (terwijl daarvoor een - directe - wettelijke basis ontbreekt). Overigens heeft de Hoge Raad in latere arresten bewust weer 'op de rem getrapt' door te overwegen dat het aan de wetgever is om (nadere) regels te stellen. Hoe dan ook is het volgens sommi-

2. Zie o.m. Rb. Noord-Nederland 2 juli 2015, ECLI:NL:RBNNE: 2015:3117, M en R 2015/126. 
gen ongepast (en ongewenst) dat de rechter het domein van de politiek betreedt.

Kortom: hoe verhouden de rechtspraak en de politiek zich - binnen het krachtenveld van de trias politica - tot elkaar? Dat is de vraag die bij deze vergadering centraal staat, zo benadrukt de voorzitter. $\mathrm{Zij}$ rondt haar inleiding af met een korte introductie van de sprekers.

\section{Inleiding mr. H.D. Tjeenk Willink ${ }^{3}$}

Stellingen:

1. De rechterlijke macht heeft zijn constitutionele positie en machtskritische functie verwaarloosd.

2. Kwaliteit is altijd gerelateerd aan functie. Zonder die relatie is kwaliteit een leeg begrip.

3. De 'verbestuurlijking' van de rechterlijke macht gaat door zolang rechters zelf geen inhoudelijk tegenwicht bieden.

4. Reflecteren is een essentieel onderdeel van de rechterlijke functie. Rechters (de rechterlijke macht) zijn (is) het reflecteren over de eigen functie verleerd.

\section{Inleiding}

Tjeenk Willink stelt voorop dat hij geen nieuw verhaal vertelt. In een nabij en verder weg gelegen verleden heeft hij zijn visie op de ontwikkelingen binnen de rechterlijke macht ontvouwd. Zeer recent in een interview in het tijdschrift Mr. van december $2015 .{ }^{4}$ Kern van al zijn verhalen is de noodzaak de inhoud van de rechterlijke functie opnieuw te ijken. Dat moet binnen de rechterlijke macht - een onafhankelijke 'macht' immers - zelf gebeuren. De discussie over de inhoud van de rechterlijke functie is urgent omdat het staatsbestel, waarvan de rechterlijke macht een onderdeel vormt, crisisverschijnselen vertoont. Wat is er binnen de trias politica aan de hand? Allereerst kent de politiek haar eigen functie niet meer. Die functie houdt in: het steeds opnieuw bepalen wat het algemeen belang vereist. Daarvoor is nodig dat de politiek over een visie op de maatschappij beschikt en op de rol van de overheid daarin. Die visie ontbreekt, aldus Tjeenk Willink. Ook de parlementaire controle op het bestuur schiet tekort. Politici zijn vooral 'medebestuurders' geworden. Het bestuur zelf heeft aan kwaliteit ingeboet door in te sterke mate de nadruk te leggen op organisatie, financieel beheer en management. Waar politiek en bestuur (dus) niet goed functioneren, komt de rechterlijke macht - als de derde macht binnen de trias - in de problemen. De rechter voelt zich klemgezet door de wetgever, die wetten als beleidsinstrument inzet. $\mathrm{Zij}$ leveren niet automatisch recht in de zin van gerechtigheid op. De spanning tussen regelgeving en gerechtigheid is groter geworden. De rechter voelt zich eveneens klemgezet door het bestuur, dat 'bedrijfsmatig werken' vooropstelt, waardoor effectiviteit en (kwantitatieve) meetbaarheid belangrijker zijn dan kwaliteit. Maar de rechter heeft ook zichzelf klemgezet: de vele reorganisaties binnen de rechterlijke macht in de afgelopen dertig jaar waren nimmer

3. Minister van Staat en oud-vicepresident van de Raad van State.

4. Interview: Herman Tjeenk Willink roept op tot verzet: 'Rechters moeten weer terug naar de inhoud', Mr. 2015, afl. 12, p. 23-29. gebaseerd op een opnieuw doordenken van de inhoudelijke functie van de rechter in het staatsbestel en zijn plaats in de samenleving. En toch hadden rechters in alle reorganisaties een werkzaam aandeel. De conclusie kan geen andere zijn dan dat geen van de drie machten binnen de trias politica duidelijk voor ogen staat wat de eigen functie - laat staan de andere functies - inhoudt. Hoe kan de overheid dan nog goed blijven functioneren?

Wat houdt de rechterlijke functie in? Volgens Tjeenk Willink - in navolging van Barak - heeft de rechter een tweeledige functie: enerzijds moet hij de kloof tussen het recht en de continu veranderende samenleving overbruggen en anderzijds moet hij de constitutie en de democratie beschermen. Wat heeft de rechter nodig aan opleiding en in zijn dagelijkse functioneren om deze tweeledige functie te (kunnen) vervullen? Is het niet zorgelijk dat binnen de juridische opleidingen het nadenken over de rol van het recht en de inhoud van de rechterlijke functie is gemarginaliseerd of onder vuur ligt? Is het niet zorgelijk dat in het dagelijkse werk het intercollegiaal overleg - waarin wederzijdse ervaringen worden gedeeld, morele dilemma's aan de orde komen en voorbeelden van mooie vonnissen worden besproken - er vaak bij inschiet? Hoe kan de rechterlijke macht als geheel zijn eigen functie bewaken als een discussie uitblijft over de veranderende rol van het recht in de samenleving en de wijze waarop de rechter daarmee omgaat; over de mogelijkheden en beperkingen van de rechterlijke functie en de betekenis van onafhankelijkheid? Tjeenk Willink is van mening dat rechters die discussie zelf moeten voeren en dat niet aan anderen - bestuurders, de Raad voor de rechtspraak - kunnen overlaten, net zomin als rechters hun intercollegiaal overleg aan anderen kunnen overlaten. Het primaat behoort bij de rechtsprekende rechters liggen.

Zonder duidelijkheid en consensus binnen de rechterlijke macht over de inhoud van de rechterlijke functie is het niet mogelijk om een vruchtbare discussie te voeren over de kwaliteit van het rechterlijke werk. Kwaliteit is op zichzelf een leeg begrip. Het krijgt pas betekenis door de relatie met de functie(s) die word(t)(en) uitgeoefend. Wat mag van een rechter worden verwacht en aan welke eisen dient de rechtspraak te voldoen? Voor een antwoord op deze vragen moet er overeenstemming zijn over wat de rechterlijke functie inhoudt. Ook daarom zijn intercollegiaal overleg en een inhoudelijk debat binnen de rechterlijke macht dringend nodig.

De essentie van de trias politica is dat er een evenwicht bestaat tussen staat en maatschappij (burgers) en binnen de staat tussen wetgever, bestuur en rechter. Evenwicht is onbestaanbaar zonder tegenwicht. Het beroep op de rechter organiseert dat tegenwicht. De rechter heeft per definitie een machtskritische functie ter bescherming van de burger tegen de macht van de staat, tegen de macht van de markt en tegen de macht van medeburgers. De rechter kan die machtskritische functie alleen goed uitoefenen in onafhankelijkheid van politiek en bestuur, maar ook onder erkenning en met respecteren van 
hun functies. Dat geldt ook omgekeerd. De 'verbestuurlijking' van de rechterlijke macht is een gevolg van onvoldoende rechterlijk tegenwicht tegen politiek en bestuur, die steeds nauwer zijn verknoopt en hun rationaliteit aan de rechter opdringen. Dat rechterlijke tegenwicht kan alleen een inhoudelijk tegenwicht zijn, ontleend aan de eigen rechterlijke functie, de eigen juridische rationaliteit en denkwijze, de eigen taal. Daarop inleveren tast de onafhankelijkheid van de rechter aan. Een goede rechter laat dat niet gebeuren.

Tjeenk Willink rondt zijn voordracht af met de opmerking dat reflecteren een essentieel onderdeel van de rechterlijke functie is. Dat geldt niet alleen voor het wijzen van vonnissen, maar ook voor het steeds opnieuw ijken van de functie zelf. Die functie wordt beïnvloed door allerlei - maatschappelijke en technologische - veranderingen. Rechters zijn weerloos tegenover die veranderingen als ze niet collectief en individueel nadenken over wat hun eigen functie inhoudt. Doen ze dat wel, dan beseffen ze wat de 'essentialia' van de rechterlijke functie zijn, en kunnen ze tegenwicht aan de wetgever en het bestuur bieden wanneer die 'essentialia' in het gedrang (dreigen te) komen.

\section{Discussie}

De heer Steenberghe (rechter) meent dat rechters het reflecteren niet verleerd zijn. Wel vraagt hij zich af wat een fundamenteel doordenken van de rechterlijke functie (concreet) zou kunnen opleveren binnen de huidige rechterlijke organisatie, waarin het accent op de beheersmatige kant van de rechtspraak ligt. Steenberghe meent dat binnen de rechterlijke macht niet zozeer een 'inhoudelijk reflectieprobleem' aan de orde is. Wel hebben rechters volgens hem te lang gedacht dat hun functie vanzelfsprekend is. In het recentelijk bekendgemaakte meerjarenplan voor de rechterlijke macht hebben de rechters zelf onvoldoende stem gehad. Dit heeft onder hen tot het besef geleid dat met hen - en ook met de inhoud van hun functie - onvoldoende rekening wordt gehouden binnen de rechterlijke organisatie als zodanig. Volgens Steenberghe behoort bij het besturen van de gerechten voortdurend de inhoud van de rechterlijke functie onder ogen te worden gezien.

In zijn reactie op deze interventie benadrukt Tjeenk Willink (nogmaals) het belang van onderlinge discussie tussen rechters over de inhoud van hun functie. Ook uit het betoog van Steenberghe volgt - zij het anders verwoord - dat rechters collectief onvoldoende duidelijk hebben gemaakt tegenover politiek en bestuur waar zij voor staan. De rechters moeten zelf nadenken over de inhoud van hun functie, want politici en bestuurders doen dat niet voor hen. De Raad voor de rechtspraak is ingesteld voor het beheer en niet voor het nadenken over de inhoud van de rechterlijke functie, aldus Tjeenk Willink.

De heer Punt (oud-rechter) merkt op dat het naar zijn inschatting uitzonderlijk is dat de rechter op de stoel van de politiek gaat zitten (zoals in de Urgenda-uitspraak lijkt te zijn gebeurd). Volgens hem gaat het binnen de rechterlijke macht uiteindelijk om feiten en geld. Hij ziet niet in welke resultaten reflecteren over de inhoud van de functie kan opleveren wanneer niet (door de politiek) extra geld voor de rechtspraak wordt uitgetrokken.

In zijn reactie hierop stelt Tjeenk Willink dat het wat hem betreft in de rechtspraak om feiten en waarden gaat. Van de rechter wordt verlangd dat hij permanent duidelijk maakt voor welke waarden hij staat.

\section{Inleiding mr. J.M. van den Berg5}

Stellingen:

1. De regievoering in de Nieuwe Zaaksbehandeling is gericht op oplossingen en al te veel verwachtingenmanagement kan in de weg staan aan de beste oplossing.

2. Het belangrijkste KEI-project is het deelprogramma Cultuur, Gedrag en Leiderschap.

3. Het is nog maar de vraag of de advocatuur een van de belangrijkste sparringpartners van de rechtspraak blijft.

\section{Inleiding}

Van den Berg merkt op dat hem is verzocht een voordracht te houden over de vraag hoever de rechter mag gaan bij het toetsen van overheidshandelen. Hij bespreekt in dit verband zowel de toetsing door de burgerlijke rechter als die door de bestuursrechter.

Van den Berg benadert de toetsing door de burgerlijke rechter in eerste instantie vanuit een historisch perspectief. Hij wijst op een drietal 'baanbrekende' arresten van de Hoge Raad uit het begin van de vorige eeuw. De Nederlandse samenleving stond destijds in het teken van grote veranderingen, met name als gevolg van de industrialisatie. Er dienden zich problemen aan die met het bestaande aansprakelijkheidsrecht niet adequaat konden worden opgelost. De Hoge Raad heeft toen enkele arresten gewezen die het aansprakelijkheidsrecht fundamenteel hebben veranderd (en waar de wetgever geen enkele bemoeienis mee heeft gehad). Art. 1275 van het oude BW bepaalde dat alle verplichtingen zich 'oplosten' in een verbintenis tot schadevergoeding. In het arrest Kieft/Otjes uit $1914^{6}$ heeft de Hoge Raad echter beslist dat de rechter in geval van een onrechtmatige daad ook bij wijze van sanctie aan de 'dader' een verbod (gericht op het voorkomen van toekomsti-

5. Advocaat te Amsterdam. Van den Berg trad op als advocaat voor de Stichting Urgenda in de door deze stichting tegen de Staat der Nederlanden aanhangig gemaakte procedure. Deze procedure is uitgemond in een vonnis van de rechtbank Den Haag van 24 juni 2015 (ECLI:NL:RBDHA:2015:7145), waarin aan de Staat het bevel is opgelegd om het gezamenlijke volume van de jaarlijkse Nederlandse emissies van broeikasgassen zodanig te (doen) beperken dat dit volume aan het eind van het jaar 2020 met ten minste 25 procent zal zijn verminderd in vergelijking met het niveau van het jaar 1990. Zie over dit vonnis o.m. R. Schutgens, Urgenda en de trias, NJB 2015/1675 en R. van Gestel \& M. Loth, Urgenda: roekeloze rechtspraak of rechtsvinding 3.0?, NJB 2015/1849.

6. HR 13 november 1914, NJ 1915/98. 
ge schendingen) kan opleggen. Daarnaast heeft de Hoge Raad in het arrest Noordwijkerhout/Guldemond uit $1915^{7}$ art. 165 van de (toenmalige) Grondwet aldus geïnterpreteerd dat de (burgerlijke) rechter bevoegd is om te oordelen over typisch overheidshandelen indien de burger zich erop beroept dat hij in een burgerlijk recht is aangetast. En in het arrest Lindenbaum/Cohen uit $1919^{8}$ overwoog de Hoge Raad dat het begrip 'onrechtmatig' uit art. 1401 van het oude BW een ruimere betekenis had dan alleen maar 'strijdig met een door de wetgever uitgevaardigde wet'. Volgens Van den Berg kenmerken deze drie arresten zich hierdoor dat:

a. de Hoge Raad er niet voor terugdeinsde om een (belangrijke) beslissing te geven in wat wij thans een 'politieke zaak' zouden noemen;

b. de Hoge Raad eigenmachtig besliste dat het terrein van de politiek ook het terrein van de rechter is; en

c. de noodzaak om burgers een adequate rechtsbescherming te bieden, de 'motor' achter deze uitspraken is geweest.

Met deze arresten werd de reikwijdte van ons aansprakelijkheidsrecht aanzienlijk uitgebreid, en dat was in die tijd politiek gezien uiterst controversieel (net zoals de aanpak van klimaatverandering momenteel controversieel is in Nederland), aldus Van den Berg.

Na 1919 heeft de rechtsontwikkeling - uiteraard - niet stilgestaan. Hirsch Ballin stelde in 1988 vast dat zich in de jurisprudentie van de Hoge Raad sinds 1951 een verschuiving had voorgedaan van 'toepassingsjurisdictie' naar 'belangenjurisdictie'.

Onder 'toepassingsjurisdictie' wordt een tamelijk mechanische toepassing van de wet verstaan, sterk leunend op de letter ervan: de rechter vinkt als het ware eerst af wat de toepasselijke regel is en bepaalt vervolgens tot welke uitkomst die regel leidt. Dit model van rechtspreken voldoet eigenlijk niet meer in een zo complexe samenleving als de huidige. Tegenwoordig spelen in het kader van één en dezelfde rechtsbetrekking vaak diverse, met elkaar botsende belangen, waardoor een conflict meerdere dimensies kent. Zo'n conflict kan niet met een eendimensionale 'simpele' regel worden opgelost. De wetgever is daarom in toenemende mate gebruik gaan maken van open normen en algemene rechtsbeginselen, zoals de goede trouw, redelijkheid en billijkheid en de maatschappelijke zorgvuldigheid. Dit soort open normen biedt de rechter de mogelijkheid tot een op het concrete geval toegesneden afweging van alle daarbij betrokken belangen. Vandaar de term 'belangenjurisdictie'. De rechter grijpt terug op de aan de wettelijke regels ten grondslag liggende belangenafweging van de wetgever. Rechtsbeginselen tenderen naar een uitkomst, maar dicteren die niet.

Overigens spelen (algemene) rechtsbeginselen volgens Van den Berg ook een belangrijke rol in een andere ontwikkeling, namelijk de toenemende invloed die het internationale recht uitoefent op de Nederlandse rechtsorde. De diverse - in het

7. HR 31 december 1915, NJ 1916/407.

8. HR 31 januari 1919, NJ 1919/161 m.nt. W.L.P.A. Molengraaf. nationale recht doorwerkende - mensenrechtenverdragen bevatten algemene rechtsbeginselen met een zware ethische lading. De doorwerking van deze beginselen wordt in de literatuur ook wel de 'constitutionalisering van het privaatrecht' genoemd. Die ontwikkeling heeft ertoe geleid dat de Nederlandse politiek minder te vertellen heeft over de Nederlandse rechtsorde. Met het (politieke) besluit om toe te treden tot een internationaal verdrag wordt als het ware een 'rechtsorde' binnengehaald die zich betrekkelijk autonoom van de nationale politiek ontwikkelt; de toepassing en de uitleg van verdragsbepalingen zijn immers vooral rechterswerk. Dit heeft tot gevolg dat de rol van de rechter (in de nationale rechtsorde) groeit, terwijl de invloed van de nationale politiek afneemt.

Van den Berg brengt ook nog een andere ontwikkeling onder de aandacht: het huidige 'neoliberale' politieke klimaat, waarin de gedachte overheerst dat de verzorgingsstaat te ver is doorgeschoten en onbetaalbaar dreigt te worden. In dit verband wordt gepleit voor een terugtredende overheid. De overheid zou minder moeten besturen en meer moeten aansturen (van 'bestuur' naar 'governance'). Hierbij past dat de politiek burgers en private organisaties een sterke actie uit onrechtmatige daad in handen wil geven. De open norm 'maatschappelijke zorgvuldigheid' leent zich daar goed voor. De hiervoor door hem geschetste ontwikkelingen hebben volgens Van den Berg met elkaar gemeen dat ze de autonomie van de rechter - ten opzichte van de (nationale) politiek - hebben vergroot. Die gewijzigde verhouding tussen rechter en politiek wordt vooral zichtbaar in gevallen waarin de rechter over de rechtmatigheid van overheidshandelen moet oordelen. In het verleden ging het om een beoordeling of de politiek c.q. het bestuur zich hield aan een rechtsorde bestaande uit zelf ontworpen regels. Thans behoort de rechter erop toe te zien dat de nationale politiek (c.q. het bestuur) zich houdt aan een - nationale rechtsorde die voor een belangrijk deel bestaat uit regels die niet door de nationale politiek zelf zijn uitgevaardigd.

Hoever mag de rechter gaan bij zijn toetsing van het nationale politieke beleid? Een algemene regel daarvoor bestaat niet. Het gaat om belangenjurisdictie en daarbij wordt ook gekeken naar de specifieke omstandigheden van het concrete geval. Van den Berg wijst er nog op dat de Hoge Raad een (lange) traditie heeft hoog te houden voor zover het gaat om de 'rechtsbescherming' tegen gevaar en bedreiging van de fysieke veiligheid. In zulke gevallen worden door de (burgerlijke) rechter duidelijke grenzen gesteld aan de beleidsvrijheid van de Staat. Genoemd kan bijvoorbeeld worden de Srebrenica-zaak uit $2013,{ }^{9}$ waarin is geoordeeld dat de ruime beleidsvrijheid aangaande militaire beslissingen geen belemmering vormde voor (civielrechtelijke) aansprakelijkheid van de Staat ter zake van een beleidsbeslissing die tot ernstig gevaar voor de betrokkenen had geleid. De Urgenda-zaak past in die traditie, aldus Van den Berg.

9. HR 6 september 2013, ECLI:NL:HR:2013:BZ9228, NJ 2015/376 m.nt. N.J. Schrijver. 
Van den Berg gaat vervolgens in op de toetsing van overheidshandelen door de bestuursrechter. De moderne bestuurswetgeving kenmerkt zich volgens Van den Berg door gedetailleerde regelgeving die in toenemende mate door het bestuur zelf buiten het parlement om - wordt vastgesteld. De door het parlement aanvaarde bestuurlijke wetten hebben vaak een procedureel karakter; zij bieden een kader voor nadere uitvoeringsregels door het bestuur. Ook in het bestuursrecht is een tendens van 'besturen' naar 'governance' waar te nemen: de minister onderhandelt, buiten het parlement om, met maatschappelijke partners en sluit met hen convenanten over het bestuursbeleid. Vervolgens meldt de minister aan het parlement te hechten aan 'maatschappelijk draagvlak' en verzoekt hij om instemming met 'flankerende wetgeving'. Een sprekend voorbeeld in dit verband is het Energieakkoord uit 2013, waarin geheel buiten het parlement om het energiebeleid voor de komende jaren is vastgelegd. Ook op het gebied van sociaal beleid, pensioenen, zorg, wonen en onderwijs zijn convenanten met maatschappelijke partners gesloten.

Wat is in deze context de rol van de bestuursrechter? Van den Berg stelt vast dat de bestuursrechter in een fundamenteel ander systeem van rechtsbescherming moet functioneren dan de burgerlijke rechter. 'Als je een systeem van rechtsbescherming ontwerpt met als vertrekpunt dat de rechter geen inhoudelijk oordeel mag geven over de gedraging waarover hij moet oordelen, dan krijg je de Algemene wet bestuursrecht (Awb)', zo merkt hij op. De Awb-rechter toetst slechts procedureel. Het gaat dus om 'toepassingsjurisdictie', niet om 'belangenjurisdictie'. De bestuursrechter kan een besluit slechts op inhoudelijke gronden vernietigen indien het 'kennelijk onredelijk' is. Gewoon 'onredelijk' is onvoldoende. Voor vernietiging is nodig dat het bestreden besluit zo onredelijk is dat geen zinnig mens daartoe had kunnen komen, aldus Van den Berg. In de Awb is het hele systeem van rechtsbescherming gebaseerd op het 'dogma' van zeer grote terughoudendheid van de rechter. Van den Berg refereert in dit verband aan het preadvies dat Hirsch Ballin in 2015 voor de VAR Vereniging voor bestuursrecht heeft geschreven. ${ }^{10}$ De conclusie van Hirsch Ballin is dat de traditionele terughoudendheid van de bestuursrechter van oudsher is gefundeerd op de democratische legitimatie van het bestuurshandelen; de werkelijkheid is inmiddels echter een andere. Hij acht het onjuist dat de bestuursrechter ervan uitgaat dat de feitenbeoordeling door het bestuur correct is en dus niet 'vol' wordt getoetst. Hij vindt het eveneens onjuist dat de bestuursrechter de beleidskeuzes van het bestuur nauwelijks toetst omdat deze tot het exclusieve terrein van de politiek zouden behoren; die beleidskeuzes 'promoveert' de bestuursrechter vaak tot zijn eigen toetsingskader. Hirsch Ballin pleit voor een indringender, meer intensieve wijze van toet-

10. E.M.H. Hirsch Ballin, Dynamiek in de bestuursrechtspraak, in: E.M.H. Hirsch Ballin, R. Ortlep \& A. Tollenaar, Rechtsontwikkeling door de bestuursrechter (Preadviezen voor de algemene vergadering van de VAR Vereniging voor bestuursrecht op 22 mei 2015), Den Haag: Boom Juridische uitgevers 2015, p. 7-58. sing door de bestuursrechter, waarin ruimte is voor een zorgvuldige afweging van de aan de orde zijnde belangen.

Van den Berg sluit zijn voordracht af met de constatering dat er een significant verschil is in toetsing van overheidshandelen tussen enerzijds de burgerlijke rechter en anderzijds de bestuursrechter. Het privaatrecht en het publiekrecht lijken zich in tegengestelde richtingen te ontwikkelen voor zover het de rol van de rechter ten opzichte van de politiek betreft: daar waar de bestuursrechter het politieke beleid te weinig toetst, zou de burgerlijke rechter volgens sommigen juist te vaak op de stoel van de politiek gaan zitten.

\section{Discussie}

De heer Hammerstein (thans waarnemend A-G bij de Hoge Raad en in het verleden ook staatsraad bij de Raad van State) merkt op dat hem is opgevallen dat er in de afgelopen vijf jaar veel is veranderd in het bestuursrecht. Niet veranderd is echter dat de rechter niet op de stoel van de bestuurder wil gaan zitten, net zo goed als de Hoge Raad niet op de stoel van de wetgever wil gaan zitten. Maar de bestuursrechter gaat volgens Hammerstein juist wel meer toe naar een belangenafweging, naar een rechtvaardige uitkomst en ook naar finale geschilbeslechting. In die zin groeien het bestuursrecht en het civiele recht juist wel naar elkaar toe. Hammersteins eigen ervaring is dat hij, op een enkele uitzondering na, aan de rechtvaardige uitkomst nooit concessies heeft hoeven te doen. De vraag is wel wie wat doet in het kader van het evenwicht tussen de machten binnen de staat. Daarin is een beweging te onderkennen die ook door Tjeenk Willink is gesignaleerd: de overheid als bestuurder die de besluitvorming zo veel mogelijk in eigen hand wil houden, drukt de rechter opzij. Of de rechter daartegen bestand is, hangt af van zijn moed bij het nemen van beslissingen, aldus Hammerstein. Volgens hem heeft de rechter die moed nog steeds. Als voorbeeld noemt hij het alcoholslot. Zowel de Hoge Raad als de Afdeling bestuursrechtspraak van de Raad van State heeft gezegd: dit kan niet. Daarna was het afgelopen. Dat geeft Hammerstein de indruk dat de rechtspraak nog altijd iets tot stand kan brengen.

In reactie op dit betoog merkt Van den Berg op dat hem niet is ontgaan dat de bestuursrechter indringender is gaan toetsen. Die toetsingsintensiteit is echter zeker niet zo indringend als bij de burgerlijke rechter. Zijn punt is dat de burgerlijke rechter de afgelopen zestig jaar heeft laten zien dat overheidshandelen best getoetst kan worden door de onafhankelijke rechter zonder afbreuk te doen aan de slagkracht van het bestuur en zonder dat de rechter politiek gaat bedrijven.

De heer Giltay Veth (advocaat) stelt dat de Wet werk en zekerheid op hem overkomt als een instrument van de overheid gericht op het 'sturen' van de rechtspraak. Nu kennen we de transitievergoeding, waar voorheen de aanmerkelijk hogere 'redelijke vergoeding' (uit het oude art. 7:685 BW) bestond. De ervaring van Giltay Veth is dat rechters nu in de praktijk vastlopen. Hij heeft een raadsheer in hoger beroep horen ver- 
zuchten: 'Das war einmal, duidend op de 'kantonrechtersformule'. Volgens Giltay Veth hadden rechters vroeger meer vrijheid, en is er nu meer sturing vanuit de politiek. De beslissing van de rechter gaat lijken op een gebonden beschikking. In zoverre onderschrijft Giltay Veth de opmerking van Hammerstein dat het aankomt op de moed van de rechter om zelf beslissingen te (durven) nemen.

Stellingen:

\section{Inleiding mr. F. Jensma ${ }^{11}$}

1. De rechtspraak moet niet zeuren.

2. De rechtspraak moet de politiek vooral vóór zien te blijven.

3. Het belangrijkste wapen van de rechter tegen de politiek is zijn ruggengraat. En zijn positie.

\section{Inleiding}

Drie waarnemingen uit de voorgaande inleidingen wil $\mathrm{ik}^{12}$ hier signaleren: (1) de inhoud van de rechterlijke functie is in gevaar en daar kan de rechter zelf wat aan doen; (2) laat de rechter zich meeslepen of biedt hij tegenwicht vanuit zijn functie; en (3) de rechter moet de kloof tussen rechtspraak en samenleving overbruggen.

Afgelopen maandag was ik in het Vredespaleis in Den Haag bij een congres over 'online dispute resolution'. Daar sprak onder meer Lord Justice Fulford, Senior Presiding Judge of England and Wales, zeg maar de Britse 'Frits Bakker'. In het Verenigd Koninkrijk heeft de rechtspraak geconstateerd dat de gouden dagen voorbij zijn, in die zin dat de wensen van de rechtspraak niet meer automatisch worden gefinancierd. Daar moest de rechtspraak zich beraden op de inhoud van zijn functie en het overbruggen van de kloof met de samenleving. In de strafrechtspleging zijn de gevolgen daarvan al merkbaar. In vier jaar tijd zal deze worden gedigitaliseerd en zal er online worden gewerkt. Van de vierhonderd gerechtsgebouwen zullen er tweehonderd worden gesloten. Dit werd als een vooruitgang gepresenteerd. Het frame van een bezuinigende overheid en gerechten die zich bezinnen, leidt ertoe dat de gerechten grijpen naar online. In Canada is bijvoorbeeld een aangepaste versie van rechtwijzer.nl (een Nederlands particulier initiatief) ingevoerd als onderdeel van de rechtspraak, nadat de gesubsidieerde rechtsbijstand in familiezaken radicaal was afgeschaft. Het biedt ons een blik op de toekomst: een digitale samenleving waarin plaats is voor privatisering van de rechtspleging waarbij rechters worden betrokken.

Aan mijn eerste stelling kunt $u$ meteen al zien dat ik me er een beetje met een jantje-van-leiden van heb afgemaakt. Rechters moeten niet zeuren, net zomin als politici, advocaten, journalisten, collega's, partners en kinderen trouwens. Waar ik op doel, is de neiging van rechters om zich - liefst per enquête -

11. Commentator NRC Handelsblad.

12. De auteurs van dit verslag hebben er - omwille van de leesbaarheid voor gekozen om de inleiding van Jensma, bij wijze van uitzondering, in de 'ik-vorm' op te nemen. te gedragen als slachtoffer van wat wel 'het management' wordt genoemd. Meestal wordt daarmee de eigen Raad voor de rechtspraak bedoeld, of de betaalmeester van de rechtspraak, 'de politiek'. De facto is dat natuurlijk de burger. We kennen het Leeuwarder Manifest uit 2012 en de enquête Tegenlicht van dit jaar - de toon wordt gezet door een groep rechters die een derde tot de helft van de rechtspraak omvat. Dus ik zal oppassen met generaliseren. Kort gezegd wijst deze groep bezuinigingen af, en ook het gros van de organisatorische veranderingen en ingrepen. De groep zegt met enige nadruk dat de rechtspraak tot 2018 'met rust gelaten' moet worden. Nu begrijp ik wel dat er veel van de rechtspraak is gevraagd de afgelopen vijf jaar - er is in deze periode meer veranderd dan in de 25 jaar ervoor. Maar zelfs dan. Wat te denken van een staatsmacht die zegt dat hij tot 2018 door de politiek met rust gelaten dient te worden, die elke vorm van verandering te veel vindt en bezuinigingen 'ontoelaatbaar', en die dat onderbouwt met zijn 'essentiële rol in de democratie'? Enerzijds deins je geïntimideerd terug; dit is immers de rechtspraak die spreekt, via een enquête. Hij bezet de enige positie in 'Heksenketel Nederland' waar het gezag nog vanzelf spreekt. Anderzijds: wie durft zich zo pontificaal boven de politiek en dus de burger te stellen als het om zichzelf gaat? Het is in politiek Den Haag vrij druk met instituties die hun essentiële functie in de rechtsstaat verdedigen, en daarmee hun budget. Maar ik ken er geen die betwist dat de politiek überhaupt over hen gaat.

Deze stelling is omarmd door de voorzitter van de Raad voor de rechtspraak, die vorig weekend op Radio 1 'het begin van het einde van de rechtsstaat' aankondigde als de politiek bezuinigingen op de rechtspraak zal doorzetten. Hij is van mening dat de rechtspraak feitelijk als Hoog College van Staat apart gefinancierd zou moeten worden - dus naar eigen behoefte, niet na een politieke afweging op het ministerie, afgewogen tegen - laten we zeggen - de noden van politie of Openbaar Ministerie. Staatsrechtelijk gezien kan ik dat best volgen. De huidige financieringssystematiek doet ook een poging om deze onafhankelijkheid te verwezenlijken, alleen blijkt in de praktijk toch het budgetplafond van de minister leidend. En zo zou het inderdaad niet moeten zijn, in een ideale wereld.

De rechtspraak is onafhankelijk en heeft het laatste woord. De meerwaarde van de rechter is dat hij geen deel uitmaakt van het bestuur, maar juist het tegenwicht vormt. De rechter als hoeder van de burgerrechten, beschermer van de constitutionele waarden en laatste toevlucht voor de burger. Heus, ik begrijp het allemaal prima. Maar zó hard de hakken in het zand zetten, dat is ook een stijlbreuk. In de praktijk doen politiek, bestuur en rechtspraak in mijn beleving immers vooral een evenwichtsoefening. De rechtspraak corrigeert, waarna 'de politiek' zich kan aanpassen. Dat zorgt regelmatig voor wrijving, maar de deur wordt nooit dichtgegooid. En dat is toch wat de rechtspraak nu lijkt te doen. Dat rechters zich zo afkeren, is nieuw. Tot nu toe gold de boosheid vooral de eigen organisatie: de Raad voor de rechtspraak en de al te gehoorza- 
me presidenten. De bezuinigingsopdracht die de rechtspraak krijgt, moesten zij zelfs 'teruggeven'.

Er zijn nogal wat rechters die de indruk hebben dat de rechtspraak afglijdt naar een doorsnee uitvoerende dienst, à la de fiscus of het UWV. Van magistraten met eigen staatsmacht voelen zij zich afgewaardeerd tot beslisambtenaren met een productieplicht en functioneringsgesprekken. Radertjes in een anonieme uitvoeringsmachine, waar ze met dossierkarretjes in rijksgebouwen naar flexplekken moeten zoeken. Tegen de burger zeggen zij dus dat er geen cent mag worden bezuinigd en geen enkele verandering meer welkom is. Dit getuigt niet van veel inzicht in wat er elders gebeurt. Van werkelijk iedere burger wordt voortdurend flexibiliteit en veranderingsgezindheid gevergd. Echt niemand is zeker van zijn budget, inkomen of toekomst. Iedereen worstelt met de gevolgen van grote maatschappelijke veranderingen, vaak het gevolg van internationale ontwikkelingen, de voortdenderende digitalisering en de permanente schaalvergroting die soevereine staten doet verdwijnen en de schaalgrootte van bedrijven opjaagt. Overheden worstelen enorm met hun rol en hun budget, ze moeten soms kunstgrepen uithalen om hun 'tax base' te behouden - de parlementaire democratie is als gevolg van een crisis in het partijstelsel sterk aan het verzwakken. Er doemen autoritaire, populistische groeperingen op, die de onzekerheid en de angst onder burgers exploiteren. Tegen die achtergrond leiden rechters, vergeleken met gewone burgers, een beschermd bestaan: ze zijn zeker van hun functie en hun loopbaan en hebben meer werk dan ze aankunnen. Maar zijn ze zich ook voldoende bewust van dit privilege? Tot 2018 met rust gelaten worden, dat willen we allemaal wel.

Ik neem graag aan dat er binnen de rechterlijke macht een vertrouwenscrisis is en er veel frustraties zijn. Maar als je een onafhankelijke staatsmacht bént, is er niks op tegen je ook zo te gedragen: zelfbewust, stabiel en met zelfvertrouwen. Maar ook graag flexibel, open, aanpassingsbereid en veranderingsbewust. Tegen rechters die klagen over gebrek aan organisatorische speelruimte, tijd voor reflectie of invloed op het zittingsrooster, zeg ik: 'Neem die ruimte gewoon.' Repareer zelf je digitale achterstand. Bepaal zelf je professionele standaarden, wat trouwens ook gebeurt, en trek daaruit conclusies. Hervorm je procedures, sluit aan bij digitale ontwikkelingen, wees duidelijk tegen de politiek over wat je rol moet zijn. Vraag je ook zelf af of het budget inderdaad naar zo veel mogelijk (deels lege) gerechtsgebouwen moet in werkelijk alle regio's. Of dat een zichtbare, toegankelijke rechtspraak, dicht bij de burger, wellicht ook sneller en goedkoper op andere manieren te realiseren is. De tijden veranderen namelijk vrolijk verder, ook als de rechters alle luiken hebben dichtgeslagen.

Dit bedoel ik met 'niet zeuren, maar doen'. Met 'de politiek voorblijven'. En je positie en ruggengraat benutten.

\section{Discussie}

De heer R. Meijer (advocaat) merkt op dat hij Jensma niet goed kan volgen. Zijn boodschap is dat je als rechter je positie moet nemen, onafhankelijk van productienormen. Maar dat moet wel mogelijk zijn. Want hoe kom je als rechter aan je bronnen als de bibliotheek wordt uitgekleed? Je kunt niet onbegrensd tijd aan een zaak besteden, want anders ontstaan er problemen in de collegiale sfeer en ook met leidinggevenden. Meijer vindt het anderzijds ondenkbaar dat de rechtspraak autonoom zijn budget zou mogen vaststellen. Dit vraagt om een 'polderoplossing'. Het appelpercentage in handelszaken is met de helft gestegen tot 30 procent. Waaraan dit ligt, weet Meijer niet, maar een potentieel probleem is het wel. ${ }^{13}$ In de jurisprudentie van de Hoge Raad ziet hij een grotere nadruk op rechtsbescherming ten koste van de rechtszekerheid en daarmee een toenemende onvoorspelbaarheid. Dit bemoeilijkt de juridische advisering en zet de leidende functie van de wetgever onder druk. Als voorbeeld wijst Meijer op de klachtplicht bij wanprestatie (ex art. 6:89 en 7:23 BW). Het signaal dat de wetgever daarmee in 1992 heeft afgegeven, is door de rechtspraak ontkracht. Onduidelijk is nu wat 'tijdig reclameren' is. In elke zaak moet een rechtvaardige oplossing worden gevonden, en dat wordt steeds lastiger.

In zijn reactie stelt Jensma dat de praktische problemen en het gebrek aan oplossingen hem fascineren. De zwakte van de rechtspraak is de loyaliteit aan het werk en aan de collega's. Bovendien hechten rechters aan bestaande kaders. Het is niet zo dat rechters geen stem zouden hebben, maar het gesprek aangaan met de ferme boodschap dat bepaalde beleidsvoornemens echt niet kunnen, past niet in de natuur van rechters. De rechter is gewend achteruit te kijken. Alle zaken die hij behandelt, spelen immers in het verleden. Het is echter nodig om vooruit te kijken, opnieuw te beginnen, op te bouwen. Anders is er over tien jaar niets aan de bestaande situatie veranderd, aldus Jensma.

Mevrouw Van Hoek (hoogleraar aan de Universiteit van Amsterdam) deelt de ervaring van Jensma. Het is tijd voor 'De nieuwe rechtspraak': rechters moeten niet zeuren, maar lawaai maken. Gekeken kan worden naar vergelijkbare problemen in andere sectoren. Denk bijvoorbeeld aan de aanval op het UvAbestuur en de opstand van de huisartsen. Die problemen komen ook voort uit een 'rendementsdenken' dat niet bij de intrinsieke functie aansluit.

Tjeenk Willink merkt op dat de rechterlijke macht - anders dan de huisartsen - vanuit zijn positie binnen de trias beter in staat moet worden geacht om tegenwicht te bieden. Overigens kan men voor een goede strategie te rade gaan bij de - succesvolle - huisartsen.

De heer Gerretsen (advocaat) refereert aan een inleiding van Vino Timmerman bij een NVvP-vergadering van enkele jaren geleden. Timmerman heeft toen de factor geluk verbonden aan de rechtsvormende taak van de Hoge Raad. Gerretsen

13. Het lijkt ons niet ondenkbaar dat dit (mede) een gevolg is van de wijziging van de competentiegrens enkele jaren geleden (Dammingh \& Van den Berg). 
vraagt zich af hoe die taak vorm kan krijgen als de rechter zelf niet gelukkig is. De gerechten hebben een bestuursstructuur die niet geluksbevorderend werkt, en dat zou dus anders moeten. De vraag is echter: hoe?

Volgens Jensma heeft het weinig zin om te klagen over de Raad voor de rechtspraak. Rechters kunnen zich volgens hem beter concentreren op hun vak. Strafrechters hebben bijvoorbeeld plezier beleefd aan het vaststellen van hun professionele standaarden. Dat is het 'wapen' om blij van te worden, dat is de route.

De heer Snijders (hoogleraar aan de Universiteit Leiden) merkt op dat de kern van de discussie in het oog moet worden gehouden. De rechter wordt gelukkiger van het vak zelf. Net als de dokter niet achter de pc wil zitten, maar zijn vak wil uitoefenen. Het vak van de rechter is subjectief recht doen. Zijn geluk is ervan afhankelijk dat hij zijn werk goed kan doen, bijvoorbeeld gedegen feitenonderzoek uitvoeren. Daar ligt een taak voor het bestuur, maar rechters moeten problemen wel signaleren en niet de positie hebben dat zij niet op de rem zouden kunnen trappen.

De heer Goethals (advocaat) wijst erop dat meer geld (voor de rechtspraak) niet automatisch tot een kwaliteitsverbetering leidt. De kwaliteit van de rechtspraak mag dan in het algemeen goed zijn, zij staat wel onder druk. Hij acht het niet wenselijk dat het budget van de rechtspraak door de politiek wordt bepaald.

De heer Jadnanansing (advocaat) brengt onder de aandacht dat de Rekenkamer heeft benadrukt dat doelstellingen goed moeten worden geformuleerd om de effectiviteit van maatregelen te kunnen beoordelen. Om te kunnen beoordelen of geld goed wordt besteed, moeten dus eerst de doelstellingen zijn geformuleerd. Een norm van een $\mathrm{x}$-aantal vonnissen per rechter lijkt hem geen goed idee. Verder moet volgens Jadnanansing bij de beoordeling van de kwaliteit van de rechtspraak ook in aanmerking worden genomen dat nogal wat justitiabelen hun onvrede over de procedure hebben geuit.

In zijn reactie op deze interventies stelt Tjeenk Willink dat de ervaring hem heeft geleerd dat het formuleren van een doel niet werkt. Het is beter om de inhoud van de functie van onderop te bepalen: rechters moeten zelf definiëren wat een goede uitspraak is. Tjeenk Willink onderschrijft de stelling dat meer geld niet zonder meer tot kwaliteitsverbetering leidt.

Volgens Van den Berg veranderen de aard en de functie van de rechtspraak niet. Reflectie blijft nodig. Van den Berg hoort nooit van zijn cliënten dat de rechter niet heeft geluisterd. Uitspraken worden steeds beter gemotiveerd. Wel is de bestuursrechtelijke uitspraak veel strakker van opzet dan een civiel vonnis, en dat draagt in het algemeen niet bij aan begrip voor de beslissing. We zijn op weg naar een 'wantrouwensamenleving'. Transparantie wordt juist verlangd als men wan- trouwt. We hebben het vertrouwen verloren in de arts, de onderwijzer en de rechter. De mens raakt uit beeld. Volgens Van den Berg gaat het erom de attitude te veranderen.

De heer Allewijn (rechter) werpt als 'positieve noot' op dat rechters zich volgens hem goed bewust zijn van de schuivende verhoudingen in de samenleving. Ze zijn loyaal, maar maken zo nodig wel een vuist. Hij noemt als voorbeeld de gijzeling van CJIB-schuldenaren, die ook werd ingezet bij mensen die niet konden betalen. In eerste instantie stelde de rechtspraak zich loyaal en welwillend op, maar later werd een nadere onderbouwing verlangd.

Tjeenk Willink merkt nog op dat ook de rechterlijke macht zijn uitgaven dient te verantwoorden, maar wel op basis van zijn taak. Het kan niet zo zijn dat zomaar een 'claim' op (meer) geld wordt gelegd. Politiek en bestuur hebben een eigen rationaliteit. De rechterlijke macht moet zijn eigen dynamiek en rationaliteit vaststellen. Niet verwacht mag worden dat de politiek en het bestuur eigener beweging de noden van de rechtspraak zullen onderkennen en lenigen.

De voorzitter constateert dat het thema van deze vergadering vele facetten kent. De boodschap is: 'Rechter, houd je rug recht, bezin je op je eigen positie en verwacht geen oplossing van de politiek.' De voorzitter dankt de sprekers voor hun inleidingen en de aanwezigen voor hun komst en inbreng en sluit de vergadering. 